\title{
New Indian Urbanism: Emerging Issues on Sustainability and Urban Ecology
}

\author{
Dr. Arup Sarkar ${ }^{1}$
}

\begin{abstract}
India is on the verge of being emerged as the most populated country of the world. To manage the massive urban population, smarter, sustainable and greener cities are envisioned in India's newly adopted urbanization policy. While smart city program with techno-infrastructure interventions for a few selected cities leave the Indian urban ecological spaces uneven, various issues on social, cultural, economic and environmental sustainability put forward challenges which are yet to be addressed. In this paper the author presented a critical analysis of current urban growth trend in the Indian urban scenario and delved into the issues on peoples' participation, inclusive planning and environmental considerations. Citing various case studies from Indian urban trends, the author argues that a comprehensive sustainable inclusive urbanization policy is attainable with convergence of the mission in practice and a vision for the future with alternative path of self reliance for the urban poor in India.
\end{abstract}

Keywords: Sustainable Development, Inclusive Planning, Smart City, Peoples' Participation

\section{Introduction}

With a total population of 1.21 billion and an annual growth rate of 1.64 percent, India is fast cruising into becoming the most populous country of the world. The success of agenda for the Sustainable Development Goals (2015) depends much on the population giants of the world and India's contribution in several fields is crucial. This paper aims to delve into the ground realities, analyze government initiatives and highlight prospects and constraints of the present situation

\section{Sustainable Development Goals}

Sustainable Development Goals are a set of seventeen global economic, social and environmental goals identified in 2015 by United Nations. It was a long journey of the UN's efforts since the United Nations Conference on the Human Environment, Stockholm during 5-16 June 1972, to bring together 193 member states of the world in its strive to address economic, social and environmental issues for a sustainable future for the planet Earth. There are 169 targets for the 17 SDG goals. Each target has indicators between 1 and 3, used to measure progress toward reaching the targets. There are 304 indicators in all that will measure compliance. It was argued that coherent and balanced trade off is necessary while implementing action plans for achieving individual goals (Nilsan 2016). This is in particular important in the Indian context.

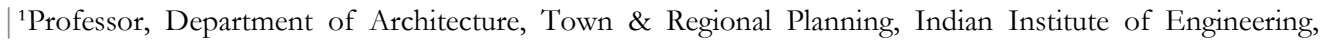
Science and Technology, Shibpur. 


\section{Trends in Population and Urbanization}

In 2011, a total number of 377 million people lived in 7935 towns/cities (census, 2011) constituting about $31.2 \%$ of the total population. The number of towns has significantly increased from 5161 in 2001 to 7935 in 2011. If we critically look into the definition of urban areas in India, a strange revelation may be obtained. As per the Census of India all places with a municipality, corporation, cantonment board or notified town area committee, etc. are urban, and all other places which satisfies the following criteria: i) A minimum population of 5,000; ii) At least 75 per cent of the male main working population engaged in non-agricultural pursuits; and iii) A density of population of at least 400 persons per sq. $\mathrm{km}$., are urban. Thus for the villages to acquire an urban tag, the three criteria are to be achieved simultaneously. For an example, Gahmar is largest village in India, situated in Ghazipur district of Uttar Pradesh. It has a population of 75,000 and failed to attain the density and male working population criteria. There are many villages in the total of 640,867 nos. of villages in India which are close and yet to be identified as urban. About 17 percent of the villages are having more than 5000 population, and their number is increasing. However, the societal demands of these villages for provision of modern amenities and services are poorly addressed ${ }^{1}$. Addressing this issue with a review on definition of urban areas, the urbanization in India may take a surprising leap ahead.

\section{Addressing Poverty and Hunger}

The National Policy for Farmers (NPF) was framed in 2007. Pradhan Mantri Krishi Sinchayee Yojana (PMKSY), an initiative on mass scale irrigation was launched in 2014 with a capital investment of 7.5 billion USD for five years ${ }^{2}$. Other government initiative, including extension of existing programs and introduced in 2014 and after, focus of various aspects such as food security, agricultural credit, crop insurance, minimum support price, e-marketplace, seed development initiatives etc.

Gross irrigated crop area in India was 82.6 million hectares, and produced 275.11 million tonnes of food grains during 2016-17 (Sally, 2017). And still the country was home to around 194.6 million undernourished people according to a 2015 report $^{3}$ of Food and Agriculture Organization (FAO) of United Nations. The 2017 report of $\mathrm{FAO}^{4}$ indicates $38.4 \%$ of children under five in India were stunted and $15 \%$ of the children remaining are hungry, $51.4 \%$ of women in reproductive ages were anemic, while obesity in adults rose from 14.6 million in 2015 to 29.8 million in 2017.

Food as a legal right was strengthened with introduction of mid-day meals at schools and

India's Villages Grow Larger, Smaller Ones Disappear, Indiaspend, October 26, 2012 http://www.indiaspend.com/investigations/indias-villages-grow-larger-smaller-ones-disappear; Accessed 3 June 2018.

${ }^{2}$ Annual Report, 2016-17, Department of Agriculture, Cooperation and Farmers welfare, Government of India; http://agricoop.nic.in/sites/default/files/Annual_rpt_201617_E.pdf; Accessed June 10, 2018.

${ }^{3}$ The State of Food Insecurity in the World, 2015. Food and Agricultural Organization, United Nations.

${ }^{4}$ The State of Food and Agriculture: Leveraging Food System for Inclusive Rural Transformation, (2017). Food and Agricultural Organization, United Nations. 
anganwadi systems to provide nutrition to pregnant and lactating mothers. The National Food Security Act (NFSA), 2013 was enacted to ensure food and nutrition security for the most vulnerable section of the society. Concerns were expressed on food security in the media (Joshi \& Fan, 2017) time and again, but it seems that for achieving SDG goal 1 and 2 India needs to have a long march ahead.

\section{Housing}

There is a severe housing shortage in India. According to Government of India, there was a shortage of 26.53 million units of housing shortage in 2012. With a revised calculation, total urban housing shortage during 2012 was re-estimated to be around 18.78 million (MHUPA, 2017). About 17 per cent of urban population amounting to 65 million lived in slums in 2011. Only 87.4 per cent of the households in urban areas and 32.7 percent in rural India have access to toilets (NIUA, 2016). 60 per cent of the metropolitan households have access to safe drinking water, while for the nonmetropolitan cities it is 51.7 percent. For non-metropolitan class I cities about 84.5 percent households have some sort of latrine in the premises, while only 28.2 percent have flush toilets with piped sewer. Homeless in Indian cities were 0.9 percent amounting to 3.4 million. There were 201 towns in 2011 where more than 75 per cent of the households practiced open defecation, and the percentage increases with size of town going smaller. Smaller town lack most of the urban amenities in much larger proportions.

'Housing for All' project aims at providing a home to every poor urban household by 2022. 'The Pradhan Mantri Awas Yojana' is being implemented during 2015-2022 and will provide central assistance to Urban Local Bodies and other implementing agencies through States and Union Territories for in-situ Rehabilitation of existing slum dwellers using land as a resource through private participation, credit linked subsidy, affordable housing in partnership and subsidy for beneficiary-led individual house construction targeting all statutory towns. 'Swachh Bharat (Clean India) Mission' aims to eradicate open defecation by 2019.

\section{Transportation}

Transportation in Indian cities is phenomenal with associated congestion, pollution, noise and crowding. Studies reveal that passenger traffic in India is likely to grow at more than $8 \%$ per year and freight traffic at more than $5 \%$ per year during the period 1990-2021 (Ramanathan \& Parikh, 1999). The nodal agency for planning and development, The National Institution Transforming India (NITI Aayog), admits in its official website ${ }^{5}$ that the progress in implementation of the provisions of National Urban Transport Policy, launched in 2006 and revised in 2014, has been far from satisfactory. Number of vehicles in India rose from 0.3 million in 1951 to 141.1 million in 2011. Personalized private vehicles such as cars and two-wheelers grew at Compounded Annual Growth Rate (CAGR) of 9.6 per cent and 10.3 percent per annum respectively

\footnotetext{
${ }^{5}$ http://niti.gov.in/content/sustainable-urban-transport-way-forward\#; Accessed 3 June 2018.
} 
between 1999 and 2009, and highest rate was recorded in the metropolitan cities. Suburban rail network too plays important role in public transport system in large cities in India. In Mumbai it carries over five million passengers daily and accounts for 58 per cent of total public transport passengers in the region, equivalent to 80 per cent of total passenger-kilometer. Kolkata, Lucknow, Chennai, Delhi, Pune, Hyderabad and Goa have suburban railway service. Operational city bus service is available in only around 65 cities among 7935 cities in total (IIHS, 2015). City railway system (Metro Rail) is in service in ten cities, and planned for seventeen cities. A Monorail system in operational in Mumbai, and there are proposals for Light Rail system in several cities. Tram, an antique mode of electric car transportation, is still operational in Kolkata.

It has been identified in several studies that lack of integration in national policies in various sectors is prerequisite for achieving the SDGs (Heeckt et.al., 2017). Urban systems become insensitive to SDGs to address short term gain. An example of such insensitivity may be a curious case of Kolkata, India's $3^{\text {rd }}$ most populous metropolitan area, where in 2012 the Kolkata Police's jurisdiction was extended to the city's peripheries, and bicycles, clubbed with cycle van, hand cart and pull cart, were banned from 174 roads $^{6}$, having been identified as slow moving vehicle causing traffic congestion. Facing severe criticism from public, traffic regulations were amended reopening 112 roads to cyclists in 2013. However, in 2014 the ban was re-imposed for 174 roads again 7 .

Over all, it is observed that India far from achieving the SDG goal number 9 (Industry, Innovation and Infrastructure), 11 (Sustainable Cities and Communities) and 13 (Climate Action) related to inputs from transportation sector, and serious efforts are desired to introduce high quality public transit system with connectivity with non-motorized mode and para-transit. Effective land use policies with transit oriented development and integrated ticketing, walking and cycling should be priority ${ }^{8}$.

\section{Urban Renewal and Smart City Program}

It is pertinent to mention on various government initiatives which were launched or revitalized since 2014 in order to address various issues related to sustainable development. 'Heritage City Development and Augmentation Yojana (HRIDAY)' program was launched to preserve and revitalize the unique character of a heritage city and facilitate inclusive heritage-linked urban development including sanitation, security, heritage revitalization, livelihoods by exploring various avenues including involvement of the private sector. 'Atal Mission for Rejuvenation and Urban Transformation (AMRUT)' aims for providing basic services (e.g. water supply, sewerage, urban transport) to households and build amenities in cities which will improve the quality of life for all. 500 cities are brought to its fold focusing on basic urban infrastructure and to bring in good

\footnotetext{
${ }^{6}$ https://scroll.in/article/828176/in-kolkata-citizens-resist-police-attempts-to-squeeze-bicycles-off-theroad; Accessed 3 June 2018.

7http://www.thehindu.com/news/national/other-states/fresh-notification-on-banning-cycles-inkolkata/article5735828.ece; Accessed 3 June 2018.

${ }^{8}$ United Nations (2017). Transport and Sustainable Development Goals Transport and communication bulletins for Asia and the Pacific, No. 87, ESCAP.
} 
governance through reforms and capacity building. 'The Smart Cities Mission' aims to promote cities that provide core infrastructure and give a decent quality of life to its citizens, a clean and sustainable environment and application of 'Smart' Solutions.

Intension of the Government of India had been reflected in various international platforms apart from notifications from time to time. Ms. Paulomi Tripathi, First Secretary in India's Permanent Mission to the United Nations, stated at the 51st Session Commission on Population and Development ${ }^{9}$ in April 2018 that development of wellplanned and fully serviced new areas or 'green-fields' around cities in order to accommodate the rapidly expanding population was a part of the urban strategy of the government of India.

\section{Concluding Remarks}

Sustainable Development Goals are interlaced and complex and achieving them needs perfect balancing in policy framework (Klopp \& Petretta, 2017). Stress more on urban systems are bound to encourage rural to urban migration in an already top-heavy urbanization in India. There is a growing concern on privacy of big data in the smart city systems (Townsend, 2013). Embedded in traditions and customs, society reacts to introduction of technologies in diverse manner. Critics argued that the smart city mission overlooks the range of inequality and diversity in Indian cities (Randhawa 2017), and unless participation of each section of the society is ensured with dialogues and sharing of responsibilities, systems are bound to crash. Achieving Sustainable Development Goals needs mutual cooperation between stakeholders and inclusive participation. With a general election of the Parliament in the horizon in every five years, India will have to strive hard to achieve it unless it has a long term plan.

\section{Reference}

Nilson, M/, Griggs, D. \& Visbeck, M. (2016). Sustainable Development Goals, Nature, 534(7607):320, AcademicOneFile; Accessed 3 June 2018.

India's Villages Grow Larger, Smaller Ones Disappear, Indiaspend, October 26, 2012 http://www.indiaspend.com/investigations/indias-villages-grow-larger-smaller-ones-disappear, Accessed 3 June 2018.

Annual Report, 2016-17, Department of Agriculture, Cooperation and Farmers welfare, Government of India; http://agricoop.nic.in/sites/default/files/Annual_rpt_201617_E.pdf; Accessed June 10, 2018.

Madhvi Sally (2017). India set for record foodgrain output in 2017-18: Agriculture ministry, The Economic Times, 27 February 2018; https://economictimes.indiatimes.com/news/economy/agriculture/india-set-forrecord-foodgrain-output-in-2017-18-agriculture-ministry/articleshow/63098420.cms; Accessed 3 June 2018.

The State of Food Insecurity in the World, 2015. Food and Agricultural Organization, United Nations.

The State of Food and Agriculture: Leveraging Food System for Inclusive Rural Transformation, (2017). Food and Agricultural Organization, United Nations.

${ }^{9}$ Business Standard, April 11, 2018. Unplanned urbanization poses serious development challenges: India to UN. Retrieved from https://www.business-standard.com/article/pti-stories/unplanned-urbanisation-poseserious-development-challenges-india-to-un-118041100233_1.html; Accessed 3 June 2018. 
Joshi, P.K. and Fan, S. (2017). Sustainable Development Goals: Strengthening rural-urban linkages is the key for India, Financial Express; 11 May 2017. https://www.financialexpress.com/opinion/sustainabledevelopment-goals-strengthening-rural-urban-linkages-is-the-key-for-india/663049/; Accessed 3 June 2018.

MHUPA (2017). Report of the technical group on urban housing shortage (TG 12) (2012-2017), National Building Organization, Government of India.

NIUA (2016). Towns of India - Status of demography, economy, social structure, housing and basic infrastructure, HSMA HUDCO NIUA collaborative Research.

Ramanathan, R. \& Parikh, J. K. (1999). Transportation sector in India: an analysis in the context of sustainable development, Transport Policy, 6(1):35-45. https://doi.org/10.1016/S0967070X(98)00030-4; Accessed 3 June 2018.

http://niti.gov.in/content/sustainable-urban-transport-way-forward\#; Accessed 3 June 2018.

IIHS (2015). Urban transport in India: Challenges and recommendations; http://iihs.co.in/knowledgegateway/wp-content/uploads/2015/07/RF-Working-PaperTransport_edited_09062015_Final_reduced-size.pdf; ; Accessed 3 June 2018.

Rode, P., Heeckt, C., Ahrend, R., Huerta Melchor, O., Robert, A., Badstuber, N., Hoolachan, A., and Kwami, C., 2017. Integrating national policies to deliver compact, connected cities: an overview of transport and housing. Coalition for Urban Transitions, London and Washington, DC. Available at: http://newclimateeconomy.net/content/cities-working-papers; Accessed 3 June 2018.

https://scroll.in/article/828176/in-kolkata-citizens-resist-police-attempts-to-squeeze-bicycles-off-the-road; Accessed 3 June 2018.

http://www.thehindu.com/news/national/other-states/fresh-notification-on-banning-cycles-inkolkata/article5735828.ece; Accessed 3 June 2018.

United Nations (2017). Transport and Sustainable Development Goals Transport and communication bulletins for Asia and the Pacific, No. 87, ESCAP.

Business Standard, April 11, 2018. Unplanned urbanisation pose serious development challenges: India to UN. Retrieved from https://www.business-standard.com/article/pti-stories/unplannedurbanisation-pose-serious-development-challenges-india-to-un-118041100233_1.html; Accessed 3 June 2018.

Klopp, J. M. \& Petretta, D. L. (2017). The urban sustainable development goal: Indicators, complexity and politics of measuring cities, Cities, 62:93-97.

Anthony M. Townsend (2013). Smart Cities: Big Data, Civic Hackers, and the Quest for a New Utopia, W W Norton Company: ISBN 0393349780.

Randhawa, A \& Kumar, A. (2016). Exploring sustainability of smart development initiatives in India, International Journal of Sustainable Built Environment, 6 (2):701-710. 